\title{
A new species of Begonia section Parvibegonia (Begoniaceae) from Thailand and Myanmar
}

\author{
T. Phutthai ${ }^{1}$, M. Hughes ${ }^{2}$
}

Key words

limestone

Southeast Asia

taxonomy

\begin{abstract}
Begonia tenasserimensis sp. nov. belongs to Begonia sect. Parvibegonia and is endemic to the hills of the Tenasserim Range, based on specimens from Peninsular Thailand and Tenasserim Division in Myanmar. The species is restricted to karst limestone and has been assessed as Vulnerable according to IUCN criteria.
\end{abstract}

Published on 9 February 2017

\section{INTRODUCTION}

Karst limestone in Thailand has an archipelago-like distribution and a rich and highly endemic flora. Many areas of this habitat are under-explored botanically, and are providing a constant source of new species and genera especially in the families Balsaminaceae, Begoniaceae and Gesneriaceae (Phutthai et al. 2009, Suksathan \& Triboun 2009, Phutthai \& Sridith 2010, Middleton \& Möller 2012, Middleton \& Triboun 2012). Limestone endemics often have very narrow distributions, which can mean high levels of threat when considered in combination with the high value of their habitat in terms of tourism and mining. Accurately documenting the species diversity of limestone karst habitat is the first step towards securing its future.

The new species described here belongs to Begonia sect. Parvibegonia A.DC. which comprises 33 species and is distributed from Northeast India throughout Indo-China to Java (Doorenbos et al. 1998, Hughes et al. 2015). Members of the section are characterised by their tuberous habit, pistillate flowers with 2 stigmas, 2-locular fruits with one enlarged wing and bifid placenta. In Thailand, 13 species are now recognised from Begonia sect. Parvibegonia (this study, Hughes 2008, Phutthai \& Sridith 2010, Phutthai et al. 2012).

Begonia tenasserimensis Phutthai \& M. Hughes, sp. nov. Fig. 1; Map 1

Begonia tenasserimensis is vegetatively similar to and shares the presence of persistent tepals when the fruit matures with $B$. crenata Dryand. but differs from that species in having an acutely lobed leaf lamina with 3 main veins (vs unlobed with 5 main veins) and a shortly spinose dentate leaf margin (vs crenate), pistillate flowers with 5 tepals (vs 6) and staminate flowers with lanceolate inner tepals (vs broadly elliptic), and a more branched inflorescence. - Type: D.J. Middleton, K. Bunpha, P. Karaket, S. Lindsay, T. Phutthai, S. Suddee \& N. Tetsana 5371 (holo E, barcode E00596936; iso BKF, PSU), Thailand, Satun, Thung Wa District, on eroded limestone with numerous pools and small waterfalls in deep shade gallery forest, N7 $06^{\prime} 40^{\prime \prime}$ E99 50 '36", 140 m, 10 Sept. 2010.

Etymology. The specific epithet 'tenasserimensis' is derived from the Tenasserim Range to where the species is endemic.

Faculty of Environment and Resource Studies, Mahidol University (Salaya campus), Nakhon Pathom 73170, Thailand;

corresponding author e-mail: thamarat.phu@mahidol.ac.th.

2 Royal Botanic Garden Edinburgh, 20A Inverleith Row, Edinburgh, EH3 5LR, Scotland, UK.
Monoecious herb, 5-20 cm tall. Stems succulent, glossy, erect, glabrous, pale green or dark red; tubers globose or subglobose, 5-10 mm diam, with numerous fibrous roots. Stipules persistent, lanceolate, pale green 4 by $3 \mathrm{~mm}$, with sparse glandular hairs. Leaves 3-5 per plant, basifixed, petiole pale green or maroon, reddish brown when dry, $1-5 \mathrm{~cm}$ long; leaf blade succulent, symmetric or subsymmetric, chartaceous when dry, adaxial surface sparsely hirsute, light green, glossy, iridescent, abaxially glabrous and glaucous; palmatifid, $4-7$ by 4-8 cm, apex shallowly trilobed, margin dentate or biserrate with short spinose hairs, base truncate or rarely cordate; venation palmate, main veins 3 . Inflorescences terminal, 5-9 cm long, a compound dichasium, bisexual, 1-4 times branched with many staminate flowers and 1 pistillate flower per branch on the lowest branch, protandrous; peduncles 2-7 cm long, terete with glandular hairs, pale green or dark red, glossy. Bracts persistent, membranous, pale green, glossy, lanceolate, with sparse glandular hairs, $2-3$ by $1-2 \mathrm{~mm}$, apex obtuse, margin entire. Staminate flowers: pedicels $4-5 \mathrm{~mm}$, erect, with glandular hairs; tepals 4 , pale magenta, outer 2 suborbicular, $4-6$ by 4-5 mm, base rounded, apex obtuse, margin entire, glabrous on both sides; inner 2 lanceolate, $3-4$ by $2-3 \mathrm{~mm}$, base obtuse, apex acute, margin entire, glabrous on both sides; androecium zygomorphic, like bunch of bananas, stamens c. 18-20, yellow, filaments c. $0.5 \mathrm{~mm}$ long, anthers oblong c. $1 \mathrm{~mm}$ long, apex retuse, dehiscing by slits near the tip, filaments fused in a column. Pistillate flowers: pedicels erect, pale magenta, 3-10 mm long; tepals 5 , unequal, pale magenta, outer 2 orbicular, 4-6 by $4-5 \mathrm{~mm}$, apex obtuse, margin entire, base rounded, glabrous on both sides; inner 3 lanceolate or oblong, 3-4 by $2-3$ $\mathrm{mm}$, apex acute, margin entire, base obtuse, glabrous on both side; styles 3, fused halfway, yellow, stigmatic band irregularly crescent-shaped; ovary with 3 wings, with glandular hairs, 2-locular, placenta bilamellate. Fruits with persistent tepals, glossy, pale green, pendulous, drying pale brown, c. 5-6 by 5-10 $\mathrm{mm}$; locule elliptic, $3-4$ by $3-5 \mathrm{~mm}$, abaxial wing facing down, slightly larger than the lateral wings, 5-10 $\mathrm{mm}$ long. Seeds numerous, brown, barrel-shaped, c. $0.3 \mathrm{~mm}$ long.

Distribution \& Ecology - Peninsular Thailand (Satun Province, Thung Wa, Than Plew Waterfall, 140 m; Ranong Province, Raksra Warin hot water spring park, $100 \mathrm{~m}$ ) and Myanmar (Tenasserim), in small crevices on eroded limestone rocks amongst numerous pools and small waterfalls in gallery forest. Flowering: July to November; fruiting: November to December. 


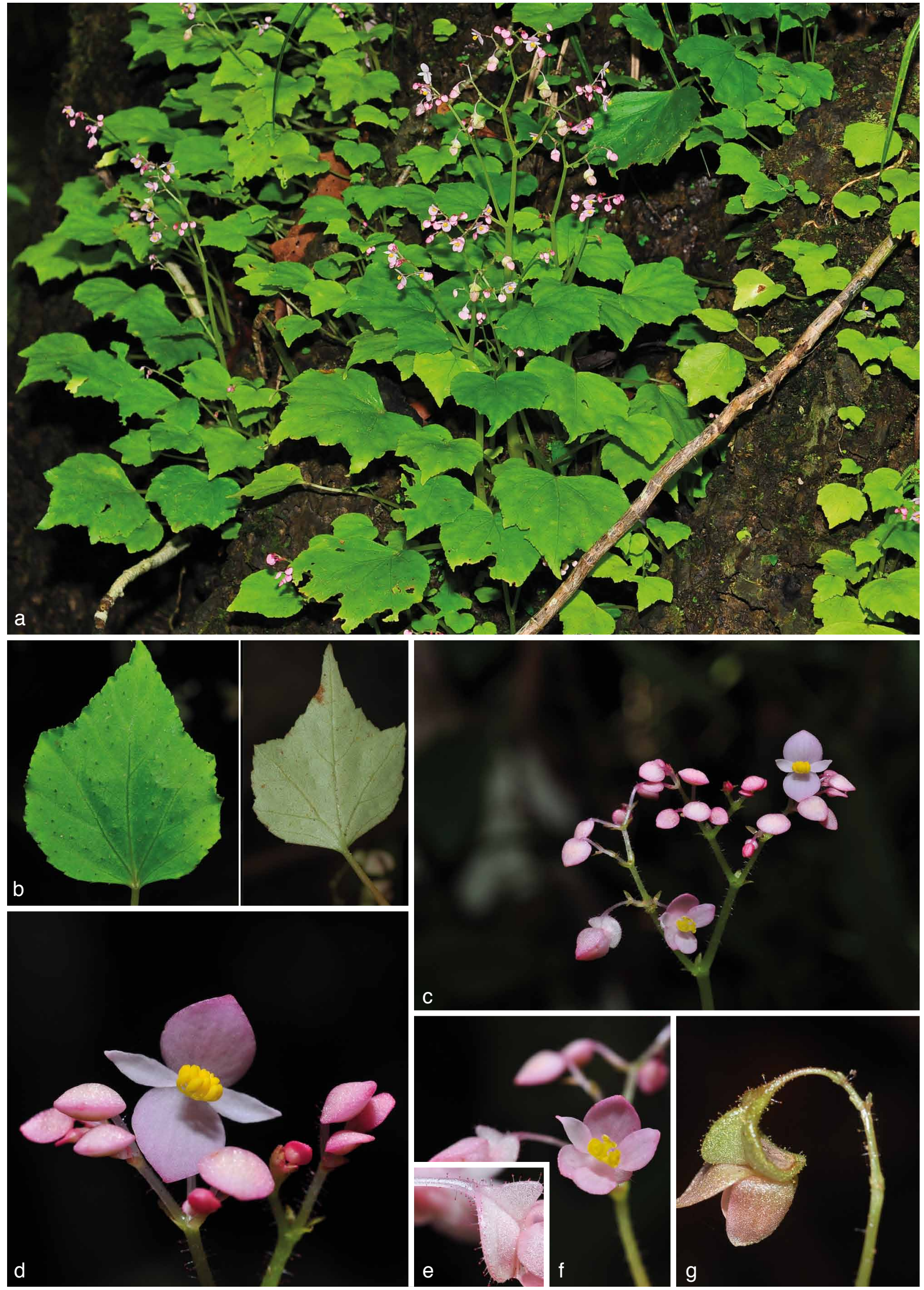

Fig. 1 Begonia tenasserimensis Phutthai \& M.Hughes. a. Habit and habitat; b. adaxial and abaxial leaf lamina; c. inflorescence; d. staminate flower; e. glandular hairs on ovary; f. pistillate flower; g. maturing capsule with persistent tepals. - Photos by Thamarat Phutthai 


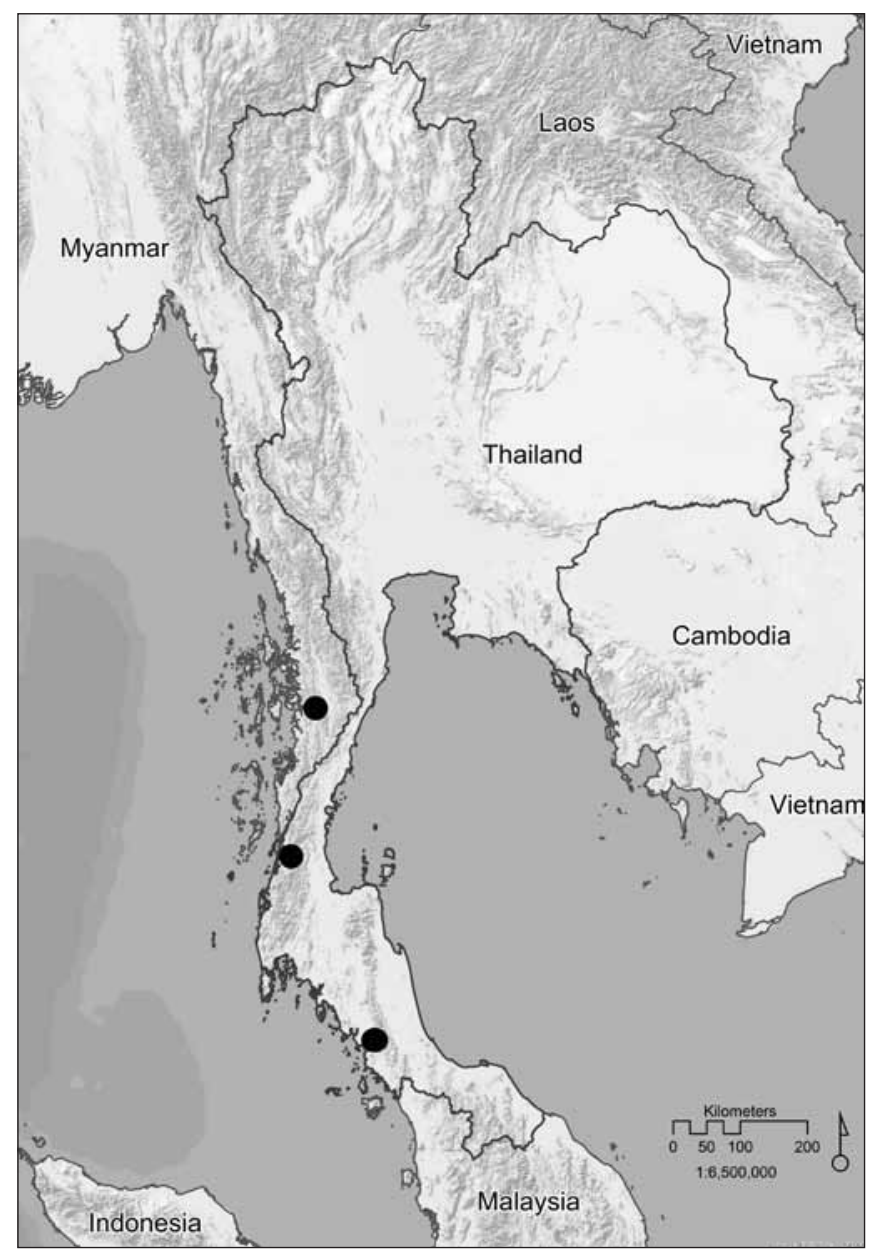

Map 1 Distribution of Begonia tenasserimensis Phutthai \& M.Hughes in Thailand and Myanmar.

Conservation assessment - Begonia tenasserimensis is known only from two karst limestone localities in Thailand and one in Myanmar, the latter collected in 1861 . Only $25 \%$ of the $20,000 \mathrm{~km}^{2}$ of karst limestone in Thailand is protected (Clements et al. 2006). The Thai populations of the species are in localities classed as recreation areas (IUCN protected area category $\mathrm{VI}$; an area which is promoted for sustainable use, where conservation and sustainable use can be mutually beneficial; IUCN 2016) and can receive many tourist visitors in the high season. The exact locality of the Myanmar collection is unknown. We consider a category of Vulnerable (VU D2) to be appropriate, as the populations are prone to the effects of human activities or stochastic events within a very short period (IUCN 2012).

Additional specimens examined. Myanmar, Tenasserim, J.W. Helfer 2584 (K), 1861-2. - Thalland, Ranong, C. Phengklai 1300 (BKF), 18 Sept. 1968.

Note - Initially we considered the specimens we here use to describe $B$. tenasserimensis a new record for Thailand of B. crenata (syn. B. aliciae C.E.C.Fischer), an endemic of the Western Ghats in India (Aitawade \& Yadav 2012), and although we are now sure they are distinct it seems they are closely allied. In addition to the morphological differences it seems they are also ecologically differentiated. Begonia tenasserimensis is a karst limestone endemic and found in lowland seasonal forest at c. $150 \mathrm{~m}$ of altitude, on eroded limestone in streams. In contrast $B$. crenata is distributed in montane forest at $900-1200 \mathrm{~m}$ altitude (Kumar et al. 2002) and is not restricted to limestone.
Acknowledgements The authors would like to thank the curators and staff of the following herbaria: ABD, BK, BKF, BM, C, HAST, K, E, L, PSU and SING. The Royal Botanic Garden Edinburgh is supported by the Scottish Government's Rural and Environment Research and Analysis Directorate. Field studies of Begonia in Thailand were made possible by the staff of the Forest Herbarium (BKF) and Dr. Somran Suddee and Dr. Rachun Pooma, Department of National Parks, Wildlife and Plant Conservation, Ministry of Natural Resources and Environment, and Dr. David Middleton, Singapore Botanic Garden. This work was supported by the Newton Fund Researcher Links programme, part of the UK's official development assistance programme administered by the British Council.

\section{REFERENCES}

Aitawade M, Yadav S.R. 2012. Taxonomic status of Begonia aliciae (Begoniaceae). Rheedea 22: 111-115.

Clements R, Sodhi NS, Schilthuizen M, et al. 2006. Limestone karst of Southeast Asia: Imperiled arks of biodiversity. Bioscience 56: 733-742.

Doorenbos J, Sosef MSM, De Wilde JJFE. 1998. The sections of Begonia, including descriptions, keys and species lists (Studies in Begoniaceae VI). Wageningen Agricultural University Papers 98: 1-266.

Hughes M. 2008. An annotated checklist of Southeast Asian Begonia. Royal Botanic Garden Edinburgh.

Hughes M, Moonlight P, Jara A, et al. 2015. Begonia Resource Centre. Online database available from http://elmer.rbge.org.uk/begonia/. Acc. 31 July 2015.

IUCN 2012. IUCN Red List categories and criteria: version 3.1. 2nd ed. IUCN, Gland, Switzerland and Cambridge, UK.

IUCN 2016. Protected areas categories. https://www.iucn.org/theme/protected-areas/about/protected-areas-categories. Acc. 5 Dec. 2016.

Kumar ESS, Jabbar MA, Salim M. 2002. Rediscovery of Begonia aliciae C.E.C.Fisch. (Begoniaceae) from the Western Ghats of Kerala. Rheedea 12: $185-188$.

Middleton DJ, Möller M. 2012. Tribounia, a new genus of Gesneriaceae from Thailand. Taxon 61: 1286-1295.

Middleton DJ, Triboun P. 2012. Somrania, a new genus of Gesneriaceae from Thailand. Thai Forest Bulletin (Botany) 40: 9-13.

Phutthai T, Hughes M, Sridith K. 2012. A new species of Begonia (Begoniaceae) from Peninsular Thailand. Edinburgh Journal of Botany 69: 287-292. Phutthai T, Sands M, Sridith K. 2009. Field surveys of natural populations of Begonia L. in Thailand. Thai Forest Bulletin (Botany) special issue: Papers from the 14th Flora of Thailand Meeting 18-21 August 2008, Copenhagen, Denmark: 186-196.

Phutthai T, Sridith K. 2010. Begonia pteridiformis (Begoniaceae), a new species from Thailand. Thai Forest Bulletin (Botany) 38: 37-41.

Suksathan P, Triboun P. 2009. Ten new species of Impatiens (Balsaminaceae) from Thailand. Gardens' Bulletin Singapore 61, 1: 174. 